Jnl of Ecclesiastical History, Vol. 69, No. 4, October 2018 . @ Cambridge University Press 2018806 doi:10.1017/Soo22046918000635

\title{
From the Universal to the Particular: Luther and the Reformation after Five Hundred Years
}

\author{
by VINCENT EVENER \\ United Lutheran Seminary, Gettysburg \\ E-mail: vevener@uls.edu
}

Martin Luther. Rebel in an age of upheaval. By Heinz Schilling (trans. Rona Johnston). Pp. xviii +613 incl. 49 figs and 4 maps. New York-Oxford: Oxford University Press, 2017. £3o. 978 o 1987222816

Martin Luther. Renegade and prophet. By Lyndal Roper. Pp. xiii +577 incl. 75 ills and 12 colour plates. London: The Bodley Head, 2016. £3o. 9781847920041

Brand Luther. 15I7, printing, and the making of the Reformation. By Andrew Pettegree. Pp xvi +383 incl. $5^{1}$ ills. New York: Penguin Books, 2016. \$1 8 (paper). $97^{8}$ o $3995^{6} 3232$

Die fremde Reformation. Luthers mystische Wurzeln. By Volker Leppin. Pp. 285 incl. 11 ills. Munich: C. H. Beck, 2016. €21.95. 9783406690815

Luther's Jews. A journey into anti-semitism. By Thomas Kaufmann. Pp. vii +193 incl. 15 ills. New York-Oxford: Oxford University Press, 2017. £18.99. 978 o 19873954 1

Remembering the Reformation. An inquiry into the meanings of Protestantism. By Thomas Albert Howard. Pp. xiii +189 incl. 20 ills. New York-Oxford: Oxford University Press, 2016. £25. 978 o 19875419 o

cholarship in recent decades has steadily chipped away at the image of Martin Luther as a figure of singular historical significance. Some have sought to embed Luther firmly in his late medieval context, and 
to situate him within a circle of reformers. Others have pluralised the Reformation, describing a diversity of ideas and movements not bound to Luther's teaching - an array of 'visions of reform' shaped by social location and gender. Social and cultural history have enriched a field long dominated by historians of theology and politics. Finally, efforts to rethink periodisation have unseated Luther and the Reformation from the turning point of history. Luther and his fellow reformers thus can find themselves at the end of an 'age of reform' that began centuries before, or in the middle of longer and more fundamental processes of social, political and religious transition.

These trends are variously reflected in the six books under review here. From his background in structural history, Heinz Schilling describes how Luther redirected secularising trends and gave impetus to 'particularising' forces in Church, society and politics. Volker Leppin insists upon Luther's medieval mystical roots, arguing that Luther's message in $15^{1} 7$ was the assertion of one medieval religious tradition against another, and tracing Luther's 'transformation' of mysticism as a reform of piety became church reform. Lyndal Roper pursues with consequence Luther's embeddedness in a broader circle of thinkers, offering a rare acknowledgement of the importance of Andreas Bodenstein von Karlstadt to the development of Luther's thought and the course of Reformation history. Thomas Albert Howard underlines how interpreters have long inscribed their perception of the 'meanings of Protestantism' - indeed, of Western history as a whole - into the memory of Luther, and he duly calls for interpretive humility that resists 'invok[ing] the Reformation as a catch-all causal agent to explain this or that, positive or negative, development in the modern world' (p. 151).

In the view of the six interpreters discussed here, Luther still appears as a figure little-rivalled in terms of historical significance, ${ }^{1}$ but the nature of Luther's influence has been redefined in several important ways. First, Luther is no longer a sui generis figure; rather, he makes a decisive intervention in ongoing religious, social-political or even technological history: Luther 'transforms' his spiritual and theological inheritance (Leppin), 'redirects' secularisation and particularisation (Schilling) and remakes the printing industry, showing its popular power (Pettegree). For Schilling, Luther was both a 'product of [longer] transition' and an agent of change (p. 38 ; and also p. 5).

Second, in the eyes of these authors, Luther's work had in the long run more unintended than intended consequences. (Schilling does attempt to

A particularly hyperbolic statement comes from the pen of Lyndal Roper, who writes that 'It was [Luther's] remarkable courage and sense of purpose that created the Reformation; and it was his stubbornness and capacity to demonise his opponents that nearly destroyed it' (p. 9). Yet Roper's book debunks the image of Luther as sole creator of the Reformation; in turn, Luther could not have 'destroyed' something so vast, although he might have helped events to proceed in another direction. 
claim an intentional legacy for Luther.) Luther initiates the Reformation, and its legacies of confessionalisation and religious strife, followed by toleration and secularisation, belong to him. The story of Luther and the Reformation still bears the weight of our perceptions of history, and these works reflect their authors' location in European and North American contexts - in societies that safeguard plural coexistence by insisting upon boundaries between secular and sacred; in societies that worry about the breaching of such boundaries by intolerance and fanaticism. When scholars in other ages and other parts of the world tell the story of Luther and the Reformation, their story will be different.

Third, several of the works under review (Howard, Kaufmann and Leppin) compellingly underline how much the nature of Luther's legacy and influence has been determined and re-determined by generations of interpreters. Interpreters have never been able to invent Luther from whole cloth without any historical data - as Howard writes, 'the actual past ... places boundaries on what can and cannot be remembered and how' (p. 4) - but Luther's story and writings have constantly been appropriated for causes that he could not have predicted. Furthermore, as Leppin points out, Protestant historians have long accepted Luther's self-depiction as someone who stood alone against a Church gone wrong and broke completely with an unbiblical, works-righteous Christianity (pp. $28-9,32-3,4^{6-7}, 5^{2}$ ). The story of the Reformation becomes the story of Luther, a man without roots, collaborators or meaningful adversaries, that is adversaries who possess plausible arguments.

Apart from Howard's study of the 'remembered past', the books here are focused upon finding the historical Luther - on understanding Luther in his own words and context, distinct from centuries of confessional and otherwise biased interpretation (Schilling, p. 3; Roper, p. 11; Kaufmann, pp. 9-11; Leppin, pp. 209-16). Their shared, overriding question is: how did Luther unintentionally become the father of confessional division and rancour - and thus the grandfather of possible coexistence through tolerance and the separation of the secular and the sacred? The authors unanimously describe Luther as someone who wanted to reform the universal Church, but who in the face of opposition - and perhaps also due to personal limitations (Roper) - settled for the consolidation of a territorial Church, consigning most of Europe to the devil. Roper, Schilling and Kaufmann all emphasise Luther's self-understanding as a 'prophet', depicting the Wittenberger's unwavering certitude of truth as the personality trait that first gave him the courage to rebel against authority, but later produced intolerance of dissent and bitter condemnation of both Christian opponents and Jews. ${ }^{2}$ Leppin's narrative offers some variation on these

${ }^{2}$ Pettegree alone casts doubt on whether Luther understood himself as a prophet (p. 324). Because the term 'prophet' is not defined in any of these works, it muddies rather than clarifies the waters. 
themes: for Leppin, Luther's initial push for a universal reform of piety and theology involved the assertion of one particular medieval tradition against others; once the battle was joined, traditions that had coexisted came to appear as irreconcilable alternatives, and political powers used Luther's teachings for purposes of 'normative centering'. No less than Roper, Schilling or Kaufmann, however, Leppin sees Luther as a self-assured figure who settled on a parochial Reformation. In this respect, the partisan use of Luther's memory depicted by Howard carried forward the reformer's legacy, although usually for purposes far distant from Luther's own.

Schilling and Roper offer comprehensive biographies of Luther, each of which hinges on Luther's turn from universal to particular aspirations. Schilling locates the turning point in Luther's response to the Peasants' War (pp. 300-3), while Roper's examination of correspondence reveals a narrowing of view already present during Luther's time at the Wartburg, when he began to correspond primarily with allies in electoral Saxony rather than a wider circle of humanists (p. 198).

Schilling's book stands apart from the others under review here in making the case that Luther's reform efforts had a direct, intended consequence. According to Schilling, Luther's 'deliberate personal legacy' consisted of the 'rediscovery of religion and faith as elemental forces for the individual and for society'. Luther not only initiated the Protestant Reformation, but 'provided the impetus' for the Catholic Reformation; in the aftermath, 'religion influenced the culture, society, and ... politics of the modern age', playing 'a decisive part in the radical transition that produced European modernity' (p. 541). Luther 'redirected the secularization that had taken hold of religion into a new "worldliness" (Welthaftigkeit)', in which 'the Christian individual and Christendom as a whole were to live out their faith' in the everyday world (pp. 542-3).

The era before the Reformation was, according to Schilling, one of progressive secularisation evident in the worldly Renaissance papacy and in the increasing autonomy of economic and social life (pp. 43, 49, 63). This secularisation occurred alongside and amid the rise of 'the militant particularism of separatist territories and nations' (p. 525), whose rulers sought authority over the Church in their realm. Against these trends, not only Luther but also the Habsburg emperor Charles v launched a 'universal project' in the sixteenth century-Luther seeking reform of the Church Universal, Charles the establishment of a Europe-wide empire (on Charles, see especially pp. 178-80, 186-8). Charles's project failed, leaving in its wake the modern state (p. $5^{26}$ ), but 'we have good reason to think Luther victorious', for he 'helped establish the terms of the debate over a new order for Latin Christendom' (p. 528). Indeed, Luther never abandoned the universalism of his original vision for church reform, even as each concrete step towards reform inevitably 
deepened particularism (pp. 356-7). More important, despite the emergence of competing confessional Churches, the Reformation initiated by Luther universally gave religious impetus and legitimacy to forms of 'cultural, political, and ideological differentiation' that had deep roots in the Middle Ages (p. 531). Even the Roman Catholic Church owes Luther a debt of gratitude, in Schilling's view, as his challenge turned the papacy's focus back to religion (pp. 2, 378, 533). Schilling summarises Luther's redirection of the stream of history as follows:

Even when viewed in the context of a longer 'age of reformations', Luther still stands out as the reformer - he consolidated existing reforming impulses and provided them with new energy and a new dynamic ... Because of Luther, the Reformation era and the period of confessionalization that followed marked the apogee of a secular turn that neither grew from nor focused on church and religion alone. (p. 527)

While the 'innovations and transitions' in European society at the end of the Middle Ages and the beginning of the early modern era had many causes, Luther made religion 'the decisive factor, in providing not only meaning and explanation but also a driving force that brought about cultural and social change' (p. 527).

Schilling's account of Luther's 'triumph' is qualified in important ways: for one, Schilling underlines that the reinvigoration of religion finally led to confessionalisation, warfare and permanent pluralism. Schilling also acknowledges that, even before these unintended consequences manifested themselves, Luther's alliance with the princes jeopardised 'his early ideals of a communal reformation', opening the door to secular interference in the internal affairs of the Church (pp. 369, 379). All nuance aside, Schilling's book reinforces tired biases of Protestant historiography, above all in the unqualified assumption that late medieval religion was in pervasive decline. The papacy, he asserts, was focused only on this side of eternity, and the laity 'no longer believed the clergy's promises about salvation' (p. 2); religion lost its 'existential power' in the midst of a 'developing anemia' (p. 533) - although of course the Church could still convincingly depict damnation (p. $5^{6}$ ). In a dubious summary, Schilling writes:

Renaissance, humanism, and, above all, the Roman curia ... had been treating religion as splendid ornamentation for culture and philosophy; an apprehensive people had either to be content with empty sacred routine, or to take flight to the irrational practices of popular religion. But Luther gave religion a new legitimacy and a new reality by means of a radical new understanding of a personal God ... For many people, both educated and uneducated, both lord and subject, both rich and poor, religion had been given back its existential significance and became the guiding principle for all thoughts and actions. The search for a single, defining quality acquired by history from Luther and the Reformation, for what was singular and exceptional, brings us to this qualitative renewal of religion. This innovation 
had its roots in the theology and devotional practices of the late Middle Ages, but it flowered only with Luther. (p. 542)

Thus, late medieval religion was for the educated and powerful a thin veneer over worldly pursuits and for others a matter of vacuous formalism or dark superstition. These are old clichés whose one-sidedness prevents a satisfactory account of Luther's legacy or that of the Reformation. 3 There is little question that Luther found a hearing in many locales because his message met a need, and little question that the challenge of Luther and Protestantism contributed to the reform and vitality of Roman Catholicism; but a proper assessment of Luther and the Reformation will require more attention to the flowering of diverse medieval reform efforts apart from Luther, including in Catholicism, and greater acknowledgement of the diversity of ways of 'being religious'. Furthermore, while the Reformation was part of Luther's legacy, it also involved other actors and had its own legacy; the two legacies are surely too rich to be reduced to a 'single, defining quality acquired by history'.

The contribution of Schilling's book lies in the effort to assess the nature and legacy of Luther's reform work in the context of longer particularising and secularising trends; thus, Schilling points the way toward a defensible estimation of Luther's agency and influence (Luther is not simply carried along by historical currents) and a possible case for Luther's 'deliberate' legacy outside the bounds of Lutheranism itself. Lyndal Roper, conversely, seeks an intimate view of Luther as a way of understanding his theological revolutions and legacies. Roper promises a 'psycho-history' or 'psychoanalytically influenced biography' grounded in sources - particularly correspondence - that provide access to Luther's mind and relationships to others. Roper sees Luther as a figure marked by psychological 'contradictions' or 'conflicts' - by unquestioned misogyny and positive regard for sex and its pleasures within marriage, by 'passionate friendships' and 'unrelenting rejections'. Roper's investigation is supposed to reveal 'why seemingly remote and abstruse theological questions [above all the real presence] mattered so deeply to him and his contemporaries' (pp. 10-1 1). Roper regards Luther's affirmation of Christ's presence in the bread and wine as 'at one with his striking ease with physicality ... A deeply anti-ascetic thinker, Luther constantly undermined and subverted the distinction between flesh and spirit, and this aspect of his thought is among his most compelling legacies. This is also why his theology has to be understood in relation to Luther the man' (pp. $15^{-16}$; see also pp. ${ }^{16} 5^{-6}, 355^{-6}$ ). This is in marked contrast to Schilling's view of Luther as the standard bearer of

3 For a more contextually-grounded discussion of the Renaissance papacy see Leppin, Die fremde Reformation, $85^{-9}$. 
inner-worldly asceticism, already on the rise in the late Middle Ages (Schilling, p. 358).

A psycho-historical contribution to the current discussion of Luther is welcome, as methodological diversity promises to yield new insight, but two deep flaws undermine this book. First, Roper's analysis avoids any explicit or detailed discussion of the Freudian theory for which she is well-known, but draws rather general inferences about Luther's personality primarily from his familial relationships, especially but not exclusively from his relationship to his father and father figures (see, for example, pp. 33, 44, 75, 314). While the lack of specificity may make Roper's book more palatable to readers who lack sympathy for psychoanalysis, the results are less challenging in terms of both methodology and conclusions. ${ }^{4}$ Renegade and prophet seems unlikely to provoke the sort of creative controversy that followed Erik H. Erikson's Young man Luther. Second, the theological principles that are supposed to be illuminated by personal psychology - principles that stand at the heart of Luther's legacy as Roper depicts it - are either not adequately described or not adequately situated in history.

The first half of the book interprets Luther's bold actions to initiate the Reformation as an outgrowing of and revolt against paternal authorities (pp. 49, 71, 125, 205-6) - a revolt that established Luther himself as a paternal figure vis-à-vis others (pp. 151-2). After retreating from 'male identity and patriarchal power' into the monastery and 'into a matriarchal world populated with female religious figures' (pp. 57-61; also p. 203), Luther found and offered Christians a God cast in the image of his own father. This God, according to Roper, was a 'distant' and 'unknowable' figure (pp. 48, 206), before whom human beings were 'utterly exposed' and had to stand 'without mediators' (pp. 30, 6o).

Regrettably, this account misses central, pervasive themes of Luther's mature theology and teaching: Luther did not sweep away all mediators to God; rather, he discovered one mediator, Christ, who makes certitude of salvation possible. Luther did experience God as wrathful and distant, but he overcame that experience through his focus on the incarnate Christ - a point Schilling underlines correctly in critique of this genre of psycho-historical claim (pp. 45-6). To draw the line from Luther's familial relationships and psychology to his image of God requires a recognition of his theological centring on the incarnation; and the absence of the latter theme from Roper's book is doubly disappointing because it would have enriched the important investigation of Luther's attitude toward 'physicality' and embodiedness. Indeed, Luther defended the doctrine of the real presence by pointing opponents to the incarnation.

4 Roper's methodology is consistent with the approach that she describes in her The witch in western imagination, Charlottesville, VA 2012, $174^{-5}$. 
While the first half of Roper's narrative, then, is about Luther's rejection of his many fathers in favour of the Father, the second is a story of how Luther became closed off from friends and allowed most of the Christian world to fall from his view, while simultaneously becoming more open to the body and sensuality (p. 199). The figure of Karlstadt looms large, and Roper's book takes seriously the depth of Karlstadt's thought and the ways in which Luther both learned from his rival (pp. 200-1, 217, 220,480 n. 13) and developed his own views through rejection of Karlstadt. Above all, however, Roper uses Karlstadt to represent a hostility toward the body and matter influenced by the Theologia Deutsch and antithetical to the direction of Luther's theology and piety (pp. 226, also pp. 236, 285, 290). Roper also recognises in Karlstadt a communal approach to reformation; thus, Luther's repudiation of Karlstadt sets the stage for his rejection of the Swiss and South German reformations, where communal action and the hard separation of spirit and matter prevailed (pp. 236-8, 256, 306-20). These clear dichotomies are, however, duly challenged by other books under review: Schilling argues for the fundamentally communal orientation of Luther's thought (pp. 357f.), and Leppin shows Luther's own roots in the mystical tradition, which Luther and Karlstadt transformed in different directions (pp. 187-207). Karlstadt's supposed revulsion toward flesh is also overstated - after all, Karlstadt was an early proponent of clerical marriage in word and deed (p. 279), and Karlstadt's mystical language of Gelassenheit had more to do with total surrender to God's will than subjection of the body.

Roper depicts Luther's doctrinal insistence on the real presence and the compatibility of spirit and matter as his 'most original' insight and a reflection of his 'ease with physicality'. Yet here Luther stood in continuity with the medieval tradition against the more innovative Reformed teachers. The connection between Luther's teachings on spirit and matter and his purported comfort with the body and sexuality is thus suspect. Indeed, the view that spirit and matter can mingle has often inspired not anti-asceticism but the reverse - the endeavour to undermine the body and allow the spirit to shine through more thoroughly. Luther's anti-asceticism (or innerworldly asceticism) eludes explanation here.

Roper also seeks to explain the anti-ascetic Luther - the monk who settled into domestic life and called other monks and clergy to do the same - as a paradoxical product of the reformer's 'gloomy anthropology' and 'radical Augustinianism'. Accepting sin as unavoidable, Luther was able to develop 'remarkably uninhibited views about sexuality' according to Roper (p. 285; also p. 421 ). In Luther's writings on marriage and monasticism, however, it is more Luther's affirmation of the goodness of God's created order (including marriage) that comes to the fore; Luther interpreted the demand for clerical and monastic celibacy as a false work imagined by human reason in rejection of God's order. Luther affirmed the 
goodness of desire, appropriately bound by marriage, because he, like Augustine, regarded marriage and procreation as created ordinances rather than divine remedies for the fall.

These criticisms aside, Roper's book is especially compelling in its description of Luther's narrowing of view. Roper illuminates the role of Luther's anger and sense of absolute certainty in this process; he was a person who 'demanded complete intellectual and spiritual submission from others' (p. 315; also p. 371), even as he was assailed with fear that he might be serving Satan (p. 320). Luther's self-identification with Christ was strong, forged in his expectation of martyrdom during the initial years of his protest (pp. 121-3, 189-93, 314-18, 325); indeed, 'Luther's own body became a battleground in the cosmic struggle between God and the devil' (p. 330). Roper analyses Luther's role in the collapse of negotiations at Augsburg from this perspective (pp. 330-42), and how Luther afterwards 'tacitly abandoned the project of reforming the Church. Instead he began to create a church of his own' (p. 343; also pp. $\left.34^{1-2}, 35^{1-4}, 362-3,412\right)$. Luther's bullying and distrust of Melanchthon set the stage for a crisis of succession (pp. 378-9; also pp. 206, 339, 408-10). In light of Roper's emphasis on Luther's anger in the context of a psychohistory, one wishes that fuller attention had been paid to his late outbursts against papists, Turks and Jews (see pp. $381-96)$.

Schilling and Roper depict Luther's retreat from ambitions for universal reform into parochialism; this narrative is affirmed with helpful nuances by Pettegree and Leppin. With his focus on printing, Pettegree shows how Luther on the one hand overcame parochialism - the parochialism of academic writing and small-town printing - to become a widely recognised 'brand'. On the other hand, Pettegree is attuned to the parochialism of Luther's alliance with the German language (pp. 332-4); the option for the vernacular made possible Luther's celebrity, but also set limits to his influence. Pettegree's book also enriches the discussion of Luther's legacy: while others attend to secularism and particularism, Pettegree sees Luther as a decisive figure in creating the modern 'appetite for news', as printers fuelled and fed demand for accounts of Luther's dramatic life (pp. 337-8).

Just as Schilling sees Luther finding his agency and influence as a participant in broader historical currents toward particularism and secularisation, so Pettegree convincingly argues that Luther was not simply a product of printing: rather, Luther intentionally and successfully capitalised on the new technology, establishing himself as a brand and transforming the book industry (pp. 24, 104-9, 335-6) and the 'reading public' (p. 144). Thus, the story of the Reformation and printing is less a story of coincidence, and more a story of Luther's effective strategy and management. 
The author repeats a number of key points throughout (first outlined at pp. xii-xiv): Luther developed a new style of theological writing, following his consequential decision to take 'the theological debate outside the academy' (pp. 79-81, 333-4); he oversaw details of production and managed the industry in Wittenberg itself, distributing work to allow multiple printers to thrive (pp. 109-14, 269-73); finally, together with Lucas Cranach, Luther helped to change the 'look of the book' (see especially pp. 157-63). The significance of Luther's pastoral writings to his reception is also duly pointed out (pp. 101, 120, 254-5).

A few critiques may be made: first, the book sometimes reads as a general biography of the reformer-frequently citing the $195^{\circ}$ work of E. G. Schwiebart - and the arrangement of the chapters, apart from the sixth, is standard fare for Luther biographies, progressing from revolution to consolidation, exclusion and church-building. One wonders if an arrangement specifically adapted to the topic at hand might have made for a more focused and provocative final product. Second, the core concept of the book, 'brand', is left without explicit definition, and the author does not answer objections that might be raised concerning the significance of Luther's brand. Pettegree underlines the poor quality of RhauGrunenberg's printings, and he sees Luther's recruitment of and work with others as decisive for the production of Luther's brand (pp. 112, $143-8,163)$. Yet Luther became a celebrity through the circulation of texts printed by Rhau-Grunenberg, which were then printed more attractively in Leipzig, Augsburg and Basel - without Luther's direct oversight. Furthermore, the wide use of Lucas Cranach's innovative title pages (pp. 157-61) may militate against the main argument: does not a brand require exclusivity? If it is simply Luther's lively, vernacular writing style that constituted the most significant and exclusive aspect of Luther's brand (see p. 338), the originality and force of Pettegree's book is lessened.

Leppin argues against historians' continued, uncritical acceptance of caricatures of medieval Christianity as un-biblical and entirely focused on human works. Rooted in Luther's own self-depictions, such caricatures obscure the reformer's 'mystical roots'. Leppin traces a number of Luther's key theological insights to the Frömmigkeitstheologie of Johann von Staupitz and the mysticism of Johannes Tauler (p. 3o)-above all, the assertion of human beings' complete dependence on grace and Christ for salvation (pp. $15,19,24^{-6}, 45^{-6}$ ), which Leppin calls the 'Grundmelodie of the later doctrine of justification' (p. 25). Leppin also shows that Luther's commitment to sola scriptura found its beginnings in his medieval teachers and sources (pp. 13, 30, 119). Luther's theology developed gradually out of these roots, particularly as he democratised and radicalised the monastic ideal of humility: for Luther, in contrast to Tauler, no 'spark of the divine'-no anthropological resource of 
goodness - remained in humans after the fall (p. 41). Leppin insists that there was no sudden discovery that separated Luther entirely from the Middle Ages (pp. 25-6, 122-3); rather, Luther himself created the myths of sudden discovery and complete rupture (pp. 28-9, 42, 52). Luther also concentrated the story of the Reformation on himself, leaving aside others like Karlstadt (pp. 32-3, 46-47).

According to Leppin, Luther in the Ninety-Five Theses wanted to say nothing more than what Tauler had said (pp. 27-31). Luther expressed a common medieval discontent with outward piety, insisting on the priority of inward contrition, although he gave this view particularly consequential expression against the sale of indulgences and - influenced by humanism voiced criticism of ecclesial authorities (pp. $5^{6-9}$ ). 'October $3^{1}$ was an intra-medieval event' (p. 6o), but in its wake diverse medieval options came to be regarded as irreconcilable (pp. 63, 152, 127). The pitting of mysticism against scholasticism turned into a contest over truth, and Luther's reform of penance and theology was caught up in the clash between decentralising and centralising views of church reform (pp. 8994). Sylvester Prierias's claims for papal authority and Luther's response to Prierias and John Eck with the appeal to Scripture alone created a Church-dividing dispute over truth and authority.

In his theology and teaching, Leppin argues, Luther 'refracted' mysticism through his Word theology; Luther completely emptied the human of resources for salvation, thus directing Christians outward to Scripture and making salvation dependent on hearing the Word (pp. 117-22) and receiving the sacraments (pp. 122-35). The image of a 'break' does not do justice to the process (pp. 121, 130) - rather, this was a 'transformation of mysticism' (p. 132).

This transformation, however, was completed within a context of division and particularism. No less than the other books reviewed here, Leppin's is profoundly concerned with the legacy of confessional division; indeed, Leppin hopes that the discovery of Luther's mystical roots will allow a rethinking of confessional boundaries (pp. 212-13). Leppin's longest chapter by far is chapter vi, 'From mysticism to politics'. In it, he briefly describes the roots of Luther's 'priesthood of all believers' in Tauler (pp. 136-7), but his primary focus is on Luther's use of the concept to legitimise the assertion of local secular authority over church reform. Luther became a political thinker (pp. $15^{6-8}$ ); and even outside his intentions, his teachings were appropriated by princes, knights, city governments and the peasantry, feeding broad currents of normative centring (pp. $1^{\mathrm{O}-1}, 159,173,179$ ). If Luther in the Large catechism remained true to the conviction that 'nothing outward makes faith, but only the inner relationship to God', he was none the less writing by that time, 1530 , in a new context, in which 'the individual territory organized its church' and evangelical Christians stood against their others, including 
the supposed papal AntiChrist. 'The impulses of mysticism, traditionally difficult to control, thereby lost their power and immediate effect', Leppin concludes (pp. 184-5). In the end, Luther himself pushed mysticism to the fringes of Lutheranism and obscured his own intellectual and spiritual roots, coming in the clash with Karlstadt, Müntzer and other 'radicals' - who shared Luther's enthusiasm for mysticism but did not follow his 'Word-theological' transformation - to express suspicion about explicitly mystical statements (p. 192) and reject any possible 'devaluation of outward religion' (pp. 204-6).

Kaufmann takes the reader on a journey from the universal to the resolutely particular by showing how Luther's prophetic self-understanding and selfcertainty first enabled and then thwarted an extraordinary reform possibility - namely, the greater Jewish participation in Christian society that Luther proposed in the early 1520 . Kaufmann situates Luther's attitude and statements concerning Jews in the reformer's sixteenth-century contexts, paying particular attention to the 'types of texts and ... communication' and the 'intended audience' of Luther's utterances (p. 10; also pp. 40-1, 54-5, 89). The book is thus a plea for historicising Luther, recognising that the anti-semitic use of Luther's writings in the nineteenth and twentieth centuries was made possible by the assumption - still widespread among some Protestants - that Luther's teachings can always be applied directly to the present situation (pp. 11, 137). Thus, any effort to find the 'real' proJewish Luther suited to our time will only perpetuate deeper patterns of thinking that make an anti-semitic Luther ever available (pp. ${ }^{156-9}$ ).

Kaufmann cautions that the line between Luther and Hitler was first drawn by German Christian and Nazi interpreters, then adopted by their opponents. Luther's aim was 'a religiously homogenous society of Christians', and he cannot be regarded as a 'leading' source for 'modern biology-inspired anti-Semitism' (pp. 8-9; also p. 113). Kaufmann ascribes to Luther, however, an 'Early Modern version of anti-Semitism' that went beyond 'religiously motivated anti-Judaism' to the association of negative characteristics with 'Jews as Jews', as a genus hominum (pp. 37, 39; also pp. 4, 114, 155). Kaufmann titles the book Luther's Jews, rather than 'Luther and the Jews', to underline the fact that Luther had little contact with living Jews; Luther's Jews were a 'phantom' constructed out of 'inherited literary sources and Biblical traditions' as well as 'ill-defined fears, calculated publishing projects ... resentment, cultural traditions, and sheer fantasy' (pp. 10, 39; also pp. 61, 90, 123, 155). Luther himself made these phantom Jews a central concern, especially by using the Jews 'as a negative foil against which to set his own teaching' (p. 10).

Chapter i explores the status of Jews within the Christian world that Luther knew, and describes the evidence surrounding Luther's limited contact with the Jews. Only at the beginning of chapter ii does 
Kaufmann state the 'central problem' of his book-unravelling why Luther, after arguing for the 'toleration of Jews within Christian society' in his 1523 treatise, That Jesus Christ was born a Jew, changed course and advocated expulsion in 1543 (p. 40). Kaufmann connects Luther's argument for toleration to 'a specifically Reformation attitude to the Jews', according to which God's promise of salvation through Christ was 'made to [the Jews] at the beginning of the history of salvation and would always remain valid' (pp. 50-2). Luther's call to bring Jews more fully into Christian society - in order to teach and preach to them more effectively - was a 'very remarkable' stance when 'seen against the background of the social, legal, and intellectual conditions of the time' (p. $\left.5^{1}\right)$. Luther's prophetic self-understanding made such a remarkable stance possible: through his own proclamation, Luther thought, Jews 'once again and for the last time before the end of the world' could hear the Word and 'simple scripture' without the veil of post-biblical tradition (p. 61). Luther set temporal bounds to toleration, however, and he interpreted the Jews' refusal to respond to his message in light of deep-seated assumptions about Jewish obstinacy (pp. 64, 83, 123-4).

No less than his bold proposal of 1523 , then, Luther's later reversal of course was fuelled by his prophetic certitude of the possession of truth (pp. 63-4). In fact, according to Kaufmann, Luther felt a sense of prophetic responsibility for the mistaken policy of 1523: 'Who could have corrected him, God's prophet and teacher of "his" church, if he did not do it himself' (p. 119; also p. 124)? Kaufmann effectively demonstrates that Luther in 1543 saw himself in a war on two fronts 'against the Jews and against the type of Christian Hebrew studies that failed to interpret the Old Testament in a Christian manner' (p. 108).

Kaufmann's concluding chapter traces the de-historicising and selective use of Luther's views over centuries of reception-history. Eighteenth-century authors influenced by Pietist or Enlightenment ideals often found in Luther 'a father of modern toleration towards the Jews' (p. 133), while nineteenth- and twentieth-century advocates of racial anti-semitism selectively republished excerpts primarily from Luther's anti-Jewish writings, removing the exegetical arguments and obscuring 'Luther's chief and most passionate concern ... to expound the Old Testament in light of Christ' (p. 143). In Kaufmann's final assessment, Luther's attitude toward the Jews was 'largely shared' by contemporaries, but was distinguished both by 'the exorbitant ferocity of his polemic and the dramatic change that occurred in his standpoint on how the Jews should be treated', as well as by Luther's extraordinary influence (p. 153). Luther's anti-Judaism cannot be 'underplay [ed]' as the 'shadow side' of his personality or theology; it had everything to do with his immersion in the Old Testament and his complete confidence that he understood 'every word' (p. 156). 
Kaufmann's deeper insights about the history of the reception of Luther are borne out by Howard's compact but illuminating study of Lutheran centenary commemorations of both the Ninety-Five Theses and Luther's birth in 1483. Howard adeptly shows how commemorators have "enlist[ed] Luther's person and actions in a much broader interpretation of the "significance," "essence," and/or "influence" of the Reformation or of Protestantism as a whole' (p. 3). Appealing to the concept of social memory, Howard argues that Reformation jubilees have both 'functioned as a crucial ritual of memory, a prophylactic against group forgetfulness and its corollary, the dissipation of identity', and 'served as a vehicle to modify identity and group consciousness, often through the politicization of memory' (pp. 6-7).

As Howard demonstrates, the year $15^{17}$ became fixed in collective memory as the beginning of the Reformation primarily due to the commemorations of 1617 , which were motivated by confessional concerns and politics. Howard identifies several common characteristics of the 1617 and 1717 commemorations - each was dominated by 'matters of religious identity'; each put Luther at the centre as the 'definitive "great man"" (pp. 11-12); and each was used by rulers to shore up political authority. Luther has remained at the centre ever since. The commemorations of 1817 , saw new directions come to the fore due to the influence of the Enlightenment, Pietism, nationalism and historicism (pp. 35-9) although 'older confessional themes' were not displaced (p. 46). Driven by 'the Enlightenment-era theme of historical progress', 1817 commemorations often enlisted Luther and the Reformation for 'a new vision of historical progress and freedom', in which the Catholic Church represented a 'massive historical impediment to progress' (p. 46). The Reformation became the fountainhead of 'modern reason, political liberalism, and/or bourgeois society', and of the 'civic virtue' and industriousness that characterised Protestant society (pp. 49-5o). Progress and German nationhood were readily connected in this view, including in the historicism of Leopold von Ranke. In $188_{3}$, then, the memory of Luther as 'the great emancipator from stultifying tradition and authority' and as 'the initiator of the modern world' could be celebrated with a nationalist bent in Germany - following upon German unification in 1871 and the ensuing Kulturkampf (pp. 68-77)-but also, in the United States, from a Whiggish historical perspective that depicted American democracy as the culmination of the Reformation (p. 77).

Inevitably, as Howard shows, twentieth-century events divided historical views still further (p. 93), first between Germany and the United States, then between Eastern Germany and the West. Outside of the GDR, the commemorations of 1967 and 1983 saw new courses shaped by ecumenism; the effort to 'denationalize the Reformation' and acknowledge its 'pan-Christian', 'pan-European' or even 'world-historical' significance; the introduction of " "post-confessional" methodologies' into the academic 
study of Luther; and, finally, greater attention to Luther's attitude toward 'Jews, Muslims, women, and peasants' (pp. 124-5).

Packing many details into a short compass, Howard's book effectively makes his central point that Reformation commemorations 'have been heavily shaped-conditioned is perhaps not too strong a word-by the milieu in which they took place. All too often, historical actors have unwittingly disfigured the Reformation by pressing it into the service of myriad ideologies, ambitions, aspirations, and interests' (p. 151). Thus Howard calls for humility and measure in interpreting the Reformation and its historical significance. He expresses hope, finally, that an honest historical assessment of the Reformation might promote Christian work toward unity. In past centennials, the work of memory has often been subject to 'partisan, xenophobic, and narrowly time-bound concerns', but 'the past is not necessarily prologue to the present' (p. 157).

Despite the differences noted throughout this review, each of the books considered here contributes to an overarching historical narrative that begins with Luther's universal reform aspirations, and ends with Luther lending his voice and authority to the consolidation of a territorial Church. Luther's enduring legacy is an unintentional one, consisting of confessionalisation and conflict, followed by toleration and secularisation - although the latter developments have been challenged time and again over the centuries by appeals to Luther himself (as Kaufmann and Howard variously show). Schilling's attempt to claim a 'deliberate' legacy for Luther beyond Lutheranism itself points scholarship in an interesting direction, but the project awaits successful execution not bound to unqualified Protestant historical biases. All these books contribute to an exalted account of Luther's role in history, not as a sui generis figure but as someone who transformed inherited traditions and catalysed and redirected broad historical forces, including secularisation, particularism and communication. While Luther's place in these historical developments seems secure, it bears remembering that scholars in other contexts and ages will inevitably and appropriately see Luther from the perspective of different legacies.

All the books under review focus on Luther primarily, and on the Reformation as an event shaped by Luther. We will understand Luther and his relationship to the Reformation better, however, the more we acknowledge that the Reformation had a life apart from Luther and a legacy apart from Luther's. We need to understand Karlstadt, other so-called 'radical reformers' and early modern Catholic leaders not only in light of Luther's response to them and their response to Luther, but also on their own terms and with respect to their own legacies. Like Luther himself, those who have remembered Luther have often wanted to forget about his precursors, collaborators and opponents, as well as his many interpreters. These figures must stand beside Luther and also bear history's weight. 